UDK 630:330.341.1(497.5)

\title{
DEVELOPMENT AND PROMOTION OF INNOVATION IN FORESTRY - INNOVATION AWARDING PROGRAMS AND SITUATION IN CROATIA
}

\author{
Razvoj i promicanje inovacija u šumarstvu - Programi nagrađivanja inovacija i situacija \\ u Hrvatskoj \\ Mario Šporčić ${ }^{1}$, Matija Landekić ${ }^{1}$, Andreja Đuka ${ }^{1}$, Matija Bakarić ${ }^{1}$
}

\begin{abstract}
Paper deals with promoting and fostering innovation in the forest-based sector. It presents concepts and initiatives which have an important role in encouraging and strengthening innovation in forestry. Two prominent international programs covered by the paper include "Schweighofer prize" which represents Innovation Award for the European Forest-Based Sector and the "KWF Innovation medal" awarded by Kuratorium für Waldarbeit und Forsttechnik - KWF (Center for Forestry Work and Forestry Technology), for the most innovative forestry developments. The overview of selected programs includes nomination and evaluation procedures, innovation categories and prizes, and particularly recent winners i.e. awarded innovations. Additionally, the paper describes the status of innovation in Croatian forestry and elaborates adopted solutions in stimulating the innovation in state-owned forest company. In this respect, indicators of relatively low innovation culture, and the regulation of innovation activity in the forest company are presented. The aim of the paper is to point out the importance of development and promotion of innovation in forestry, raise the awareness about innovation, and ultimately contribute to the stimulation of innovation activities and development of innovation culture in forestry.
\end{abstract}

Key words: forestry, innovation, innovation awards, promoting innovation, Croatia

\section{INTRODUCTION - Uvod}

Innovation generally signifies successful introduction of novelties. It is very closely related to creativity, but while creativity represents the ability to discover or find new ideas, innovativeness is the ability to transform these new ideas into useful products or services (SRIĆA, 2003). Innovation is often identified with technological innovation, but modern innovation literature distinguishes at least two categories of innovation, i.e. product innovations (changes in company's outputs which can be goods or services) and process innovations technological innovations or innovations in the company's organization) (RAMETSTEINER ET AL. 2005). Innovation is in business context usually understood as a process of a firm, which mainly has a linear conception, focuses on a firm level and occurs in several different stages (ROGERS,

\footnotetext{
${ }^{1}$ Faculty of Forestry University of Zagreb, Department of Forest Engineering, Croatia
} 
1995). On the other hand, it could also be described as a more iterative, complex nonlinear phenomenon involving a range of actors and different interactions included in the innovation system model (RAMETSTEINER and WEISS, 2006). According to the degree of novelty, innovation can be "new to the firm" (already established in the market, but newly introduced in specific firm), "new to the market" (newly introduced on its market), or "new to the world" (introduced for the first time for all markets and industries) (OECD, 2005). It can be classified as radical innovation - if it has a significant impact on a market and on the economic activity of firms in that market, or as incremental innovation - if it involves substantial improvements of existing products (OECD, 2005).

Innovation is a complex notion, and as most of the general concepts, it is difficult to describe it unambiguously and give a single widely accepted definition. One of the first essential sources in innovation theory (SCHUMPETER, 1911) defines innovation broadly, as a discontinuously occurring implementation of new combinations of means of production. Technological innovation is non-trivial change in products and processes where there are no previous experiences (NELSON and WINTER, 1977). Innovation is also argued as the successful implementation of creative ideas within an organization (AMABILE et al. 1996), or as the introduction of a new thing or method, i.e. "embodiment, combination or synthesis of knowledge in original, relevant, valued new products, processes or services" (LUECKE and KATZ, 2003). It is also defined as intentional discontinuous change in products, processes or outputs of an enterprise (RAMETSTEINER and WEISS, 2006).

According to Oslo Manual which provides guidelines for collecting and interpreting innovation (OECD, 2005) innovation is the implementation of a new or significantly improved product (good or service) or process, a new marketing method, or a new organizational method in business practices, workplace organization or external relations. This broad definition encompasses a wide range of possible innovations, and it defines four main groups of innovation: products, process, marketing, and organization.

The primary, minimum requirement for an innovation is that product, process, marketing method or organizational method must be new (or significantly improved) to the firm, and it must have been implemented (introduced on the market or brought into actual use in the firm's operations) (OECD, 2005). Other standard features of innovation, are the following: innovation is associated with risk and uncertainty; it involves investment; it is subject to spillovers; it involves the utilization of new knowledge or a new use or combination of existing knowledge; it aims at improving firm's performance by gaining a competitive advantage (OECD, 2005).

The relationship between innovations and business performance is being considered in various research, highlighting the importance and a substantial impact that innovations have on efficacy and performance of businesses (PRAJOGO, 2006; ZAIED et al. 2015; CUEVAS-VARGAS et al. 2016; SILVA, et al. 2017; MADONSELA et al. 2017). This is not only relevant for high-tech industries but to all sectors and economies, including forestry (WEISS et al. 2011; LASKOVA andi POSAVEC, 2011; 
SEELAND et al. 2011; ŠPORČIĆ, 2012; JARSKÝ, 2015; KAAKKURIVAARA et al. 2016; BOSTON et al. 2017; ŽIVOJINOVIĆ et al. 2017. Many of the research also emphasize the importance of strengthening innovation activities and necessity of fostering and encouraging innovation (KUBECZKO et al. 2006; CROPLEY, 2009; STEELMAN, 2010; POSAVEC et al. 2011; SARVAŠOVA et al. 2014; PEZDEVŠEK MALOVRH et al. 2017).

Considering that importance of innovation in forestry has been recognized, together with the need to encourage forestry innovations, this paper provides the overview of specific initiatives and programs which play an important role in promoting and fostering innovation in forestry. One of these programs is the "Schweighofer prize" which represents Innovation Award for the European ForestBased Sector. The other program is the "KWF Innovation Medal" given by the German Kuratorium für Waldarbeit und Forsttechnik - KWF (Center for Forestry Work and Forestry Technology). Additionally to two European examples of evaluating and awarding innovations in forestry, the paper describes, as a case study, the status of innovations in Croatian forestry and the adopted solutions in stimulating the innovations in state-owned forest company. The intention is, in this way, to raise the awareness of the importance and role of innovation in forestry, what ultimately should contribute to the stimulation of innovation activities and development of innovation culture in forestry.

\section{Importance and Role of Innovation - Značenje i uloga inovacija}

Innovation is the cornerstone of today's business practice and a driving force of the modern economy. Economic research has confirmed innovation as a key engine for economic growth, competitiveness, and employment (RAMETSTEINER and WEISS 2006). This made innovations, creativity, and innovativeness increasingly important and inevitable issue in the analyses of efficiency and achievements of companies, industries, regions and national economies.

Innovation has been recognized at the level of a common European (EU) policy, and it is the key element of the "Europe 2020" strategy, as it was previously in the „Lisbon strategy”, (economic development policy of the EU). In line with that, innovation is one of the five clear objectives, and creation of innovation-friendly environment (Innovation Union) is one of the seven flagship initiatives of the "Europe 2020 strategy" (EC, 2010). Accordingly, the EU Framework Programme for Research - Horizon 2020 focuses on innovation, in addition to completing and further developing the European Research Area (EC, 2011). With the efforts invested in increasing the innovation activities in Europe's economy, EU strives to create smart, sustainable and inclusive growth, and improve its competitiveness and productivity. In the pursuit of these objectives 'knowledge triangle' (research, education, and innovation) is a major factor for their accomplishment (OJUROVIĆ and GRBAC, 2007).

On the firm level, for many thriving companies, innovations are the key factor in their growth and development. In complex conditions of numerous and strong 
competition, all companies are forced to invest in research and innovation if they want to survive and be successful. Otherwise, if they neglect innovation, companies are destined for declining, poor business results, and lack of development. Such companies are eventually overcome by the surroundings and rivals which innovate efficiently (POSAVEC et al. 2011).

The main reason why companies innovate lies in the improvement of their performance, for example by increasing demand or reducing costs. The influence of innovation on the company's business ranges from effects on sales and market share to changes in productivity and efficiency. Innovation can also improve companies' performance by increasing their ability to innovate (OECD, 2005). Important effects on the level of national economies and individual industries are also (positive) changes in international competitiveness and overall productivity, knowledge spillovers from innovation in businesses and increase of the total amount of knowledge in networks (RAMETSTEINER et al. 2005).

In a forest-sector policy context, back in 2003 Ministerial Conference on the Protection of Forests in Europe (MCPFE) adopted the Vienna resolution on the "Economic Viability of Sustainable Forest Management", which states the need to "enhance the competitiveness of the forest sector by promoting innovation and entrepreneurship among all relevant stakeholders" (MCPFEE, 2003). In Madrid resolution "Forest sector in the center of Green Economy" from 2015, MCPFE again expresses the necessary commitment to "promote innovation and research by (...) encouraging the development of a culture of innovation' and 'facilitate both policy development and innovation for the long-term competitiveness of the whole forest sector" (MCPFEE, 2015). EU Forest strategy (EC, 2013) also repeatedly stresses the significance of innovation in responses to the challenges and opportunities that forestbased industries face.

Innovations in forestry are being developed and implemented, similarly as in other industries, to improve the competitiveness of forest company, national forestry, or entire forest sector vis a vis other players in the economy. Forestry is also, together with the invoked innovations in the sector, directly involved in the development of rural areas as one of the primary goals of EU. Global changes and processes are inevitably affecting the forest-based sector, which along with its own technological, organizational, productional, recreational and other innovations, must become competitive and profitable on a global scale. Here it is assumed, that development of forestry and wood processing industry, besides growth or a quantitative change, primarily must come from qualitative change in thinking and doing (POSAVEC, 2009). To accomplish that it is necessary to integrate the innovation policy into the forestry development strategy that needs to be coordinated with other areas (RAMETSTEINER et al. 2005; MARTINIĆ et al. 2006). 


\section{MATERIAL, METHODS AND AIMS - Materijal, metode $i$ ciljevi}

Paper deals with two programs aimed at promoting and awarding innovations in forestry. Presented programs are of an international character, and they invite forest-related companies to submit their innovative solutions and enter the competition for the innovation award. In one example, the organizer of the competition is the Austrian Schweighofer family, i.e. foundation, which gives "Innovation Award for the European Forest-Based Sector". In the second case, competition for "KWF Innovation Medal" is organized and given by the German Kuratorium für Waldarbeit und Forsttechnik (KWF) at KWF-Expo forest fair, as a part of the traditional KWFTagung (KWF Days) event, one of the most important forest technology events in Central Europe and one of the biggest forestry demo-fairs in the world.

The overview of selected programs includes nomination and evaluation procedures, innovation categories and prizes, and particularly recent winners, i.e. awarded innovations. The overview is made by available online sources, where Schweighofer and KWF websites were searched, as well as related websites of awarded companies/innovations and other online materials.

The case study of status and stimulation of innovation in Croatian forestry is presented from previous research [38] and the analysis of state forest company's official documents regulating innovation activity.

The set task of the paper is to elaborate:

- main features of two prominent innovation-awarding programs in forestry,

- recently awarded innovations in forestry,

- status and regulation of innovation activity in the state forestry of Republic of Croatia (RC).

The aim is to point out the importance of development and promotion of innovation, raise the awareness about innovation, and ultimately contribute to the stimulation of innovation activities and development of innovation culture in forestry.

\section{RESULTS - Rezultati}

\section{Schweighofer Prize, Innovation Award for the European Forest-based Sector -} Schweighofer nagrada, inovacijska nagrada za europski šumarski sektor

Schweighofer prize represents Innovation Award for the European ForestBased Sector. It is donated by the Austrian Schweighofer family since 2003 it awards innovative ideas, technologies, products, and services. The award is presented every second yearand is endowed with a total money prize of $€ 300,000$.

The Schweighofer Prize covers almost the whole range of topics relating to the European forest-wood-chain, excluding the pulp and paper sectors. As it explicitly enhances multidisciplinary and close cooperation between industry and research, there is no strict classification of topics. The examples below serve as general orientation of the covered topics: 
- innovative processes and technologies enhancing sustainable availability and efficient use of forest biomass,

- improved methods for sustainable forest economy and wood supply,

- advanced technologies for primary wood processing,

- innovative manufacturing methods and technologies for wood products,

- innovative wood products and systemic solutions in the fields of housing and construction,

- new packaging solutions using wood,

- new possibilities of using wood and its components (includes engineered wood products and hybrid solutions, where wood as a key component is clearly visible),

- new recycling concepts and recycled products made of wood,

- innovative multinational co-operation initiatives enhancing communication and $\mathrm{R} \& \mathrm{D}$ within the whole value chain of wood,

- leading education and training measures to strengthen the European competence in wood and wood products,

- novel innovation systems and service facilities as well as networks for wood and wood products on a European level.

All natural persons or groups of individuals, as well as organizations, are eligible to compete for the award. Call for contributions is usually opened between November and February, and all submissions must be made online. The applicants have to fulfil all conditions in form and content, and prove to the jury, made up of prominent forestry experts, the obvious benefit for the European Forest-Based Sector as the most important requirement for the award.

The other features of Schweighofer prize include:

- innovation prizes are granted for promising innovative projects, which still may be in stage of implementation,

- the projects must show obvious and verifiable innovation compared to the current state-of-the-art,

- a realistic and structured implementation concept has to be presented,

- the applied innovation must be appropriate for a European wide (industrial) implementation,

- the submissions have to be prepared by the candidates themselves,

- the total prize money is $€ 200,000$ that is mostly shared between three to six prize winners,

- the main prize awards people who have shown outstanding performance for the European forest-based sector over an extended period, and is endowed with $€$ 100,000. (source: www.schweighofer-prize.org)

\section{Awarded innovations in 2017 - Nagrađene inovacije u 2017. godini}

At the last award ceremony in Vienna 2017, the winners of Schweighofer prize came from Switzerland, Sweden and Austria. Awarded were the following innovations: 
- ERNE portal robot - robotics installation for the manufacture of highly complex components for timber construction. The installation comprises seven axles and a flexible tool changing head allowing the use of various tools for additive component manufacture. Similar to a 3D printer, the installation can process, cut, join and attach a variety of components (Photo 1). Developed by: ERNE AG Holzbau, Switzerland (more at www.erne.net).

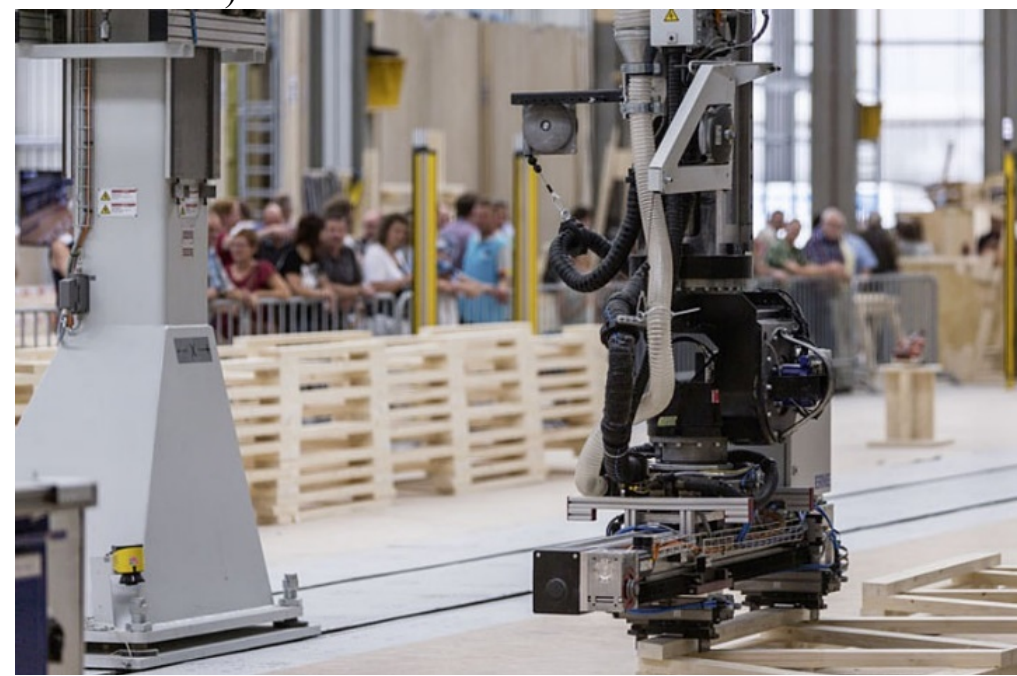

Photo 1. ERNE portal robot (source: www. www.erne.net)

Slika 1. ERNE portal robot (izvor: www. www.erne.net)

- Prowood graduate school - interdisciplinary, Swedish doctoral programme supports research-based innovation and increases the competitiveness of the timber industry. The focus is on the competition of the "best minds" for the timber industry and the realisation of products with a practical application in the industry, comprising the entire process, from conception to implementation. Developed by: Jönköping University and Linnaeus University, Sweden (more at www.prowood.se).

- CSM heartbeat - detects oscillations of saw blades in sawmills caused by overstrain by using sonic measurement through adapted measuring microphones, specialised measuring electronics and a software programme. A signal sent to the saw control then reduces the feed rate by approximately $30 \%$ for $1-2$ seconds resulting in reduced unplanned production downtimes caused, increased feed rates and reduced saw blade thickness. Developed by: Fellner engineering Gmbh, Austria (more at http://www.saw-monitoring.com).

- Calibrated route finder - provides alternatives for finding routes for lorries transporting timber and forest biomass considering distance, routing time, road quality, as well as stressful situations and road safety. Taking into account economical, social, ecological and traffic safety factors, in this way over 1500 "key routes", have been defined in Sweden. Developed by: Skogforsk Forestry Research Institute, Sweden, (more at www.skogforsk.se). 


\section{KWF Innovation Medal - KWF medalja za inovacije}

KWF Innovation Medal is awarded by Kuratorium für Waldarbeit und Forsttechnik (KWF; German Center for Forestry Work and Forestry Technology) as a prize for the most innovative forestry developments/products presented at the KWFTagung (KWF-Meeting). KWF-Tagung is the biggest Forestry Demofair in the world and the most important international meeting of the forest sector. Traditionally, the KWF- Meeting consists of three elements - KWF-Expo (formerly the Forest Machine and Innovations Show), field trips and a scientific congress. At KWF-Expo trade show over 500 national and international exhibitors from more than 25 countries (participants in 2016) present their latest developments and state-of-the-art technologies from a wide range of forest technological application fields including ICT (information and communication technology), wood transport, municipal technology, energy technology, work safety, etc.

The most innovative forestry developments of the exhibiting companies and institutions are awarded a KWF innovation medal. The prize winners are determined in a two-stage process. In the first step, all interested exhibitors are called upon to submit their designs in a brief and concise form, clearly and convincingly explaining the novel and advantageous characteristics of the registered product. These meaningful short applications are evaluated by the expert committee, which selects the most promising products and nominates them as medal candidates. The applicants who overcome this first hurdle are informed of their nomination and receive the opportunity to subsequently submit additional detailed application material for the award decision. All nominated innovations are then entered in the list of innovations, which is made available to the trade press and published on the KWF website.

Which products from among the nominees will be deemed the winners, receiving the Innovation Medal, is decided by the jury of neutral and independent members of the commission, shortly before the award ceremony at KWF-Expo. During the presentation of the winners, all nominated products - initially divided into categories - are once again presented to the public as part of the ceremony. Subsequently, the winner(s) for each category is/are announced.

The KWF Innovation Medal is awarded in the following categories:

- Forestry equipment

- Machines/Tools

- IT Applications

- Personal Protective Equipment

- Transports \& Logistics

- Accessories

A newly designed product is awarded KWF Innovation Medal if the function has changed dramatically and if its use makes a new method possible or substantially changes and improves a known method. Factors decisive for selection include the likely impact on the utility value, business, occupational health and safety, the environment and the energy situation (source: www.kwf-tagung.org). 


\section{Awarded innovations in 2016 - Nagrađene inovacije u 2016. godini}

At the last, 17th KWF-Meeting held in southern Germany (Roding, 9-12 June 2016), KWF Innovation Medals were awarded for the eighth time. Among more than 80 submissions the following innovations were rewarded.

In the Forestry equipment category, for the Ergonomics area of application:

- Ponsse Buffalo AF (Active Frame) - a three-piece vehicle chassis novel for forwarders, with front end suspended in free-floating fashion and actively leveled bogie axle, enabling a horizontal position of the cab even on a highly irregular ground surface (Photo 2). Developed by: Ponsse Oy Finnland \& Wahlers Forsttechnik GmbH (more at www.ponsse.com; www.wahlers-forsttechnik.de).

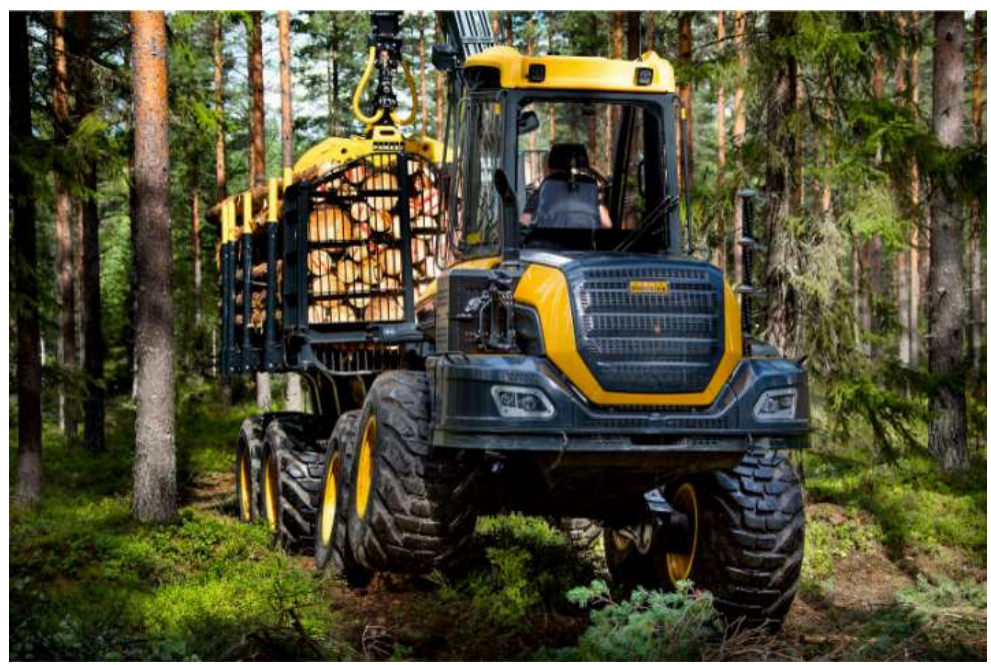

Photo 2. Ponsse Buffalo Active Frame chassis on forwarder (source: www.kwf-tagung.org) Slika 2. Ponsse Buffalo aktivni okvir šasije forvardera (izvor: www.kwf-tagung.org)

In the Forestry equipment category, for the Felling of wood area of application:

- Krpan GP12 D forestry trailer - a novel patented chassis with a hydraulic continuously adjustable bogie axle, operated from the driver's cab, and used to adjust the vertical load on the drawbar when working and for transportation on public roads (Photo 3). Developed by: Pišek-Vitli Krpan Ltd (more at www.vitlikrpan.com). 


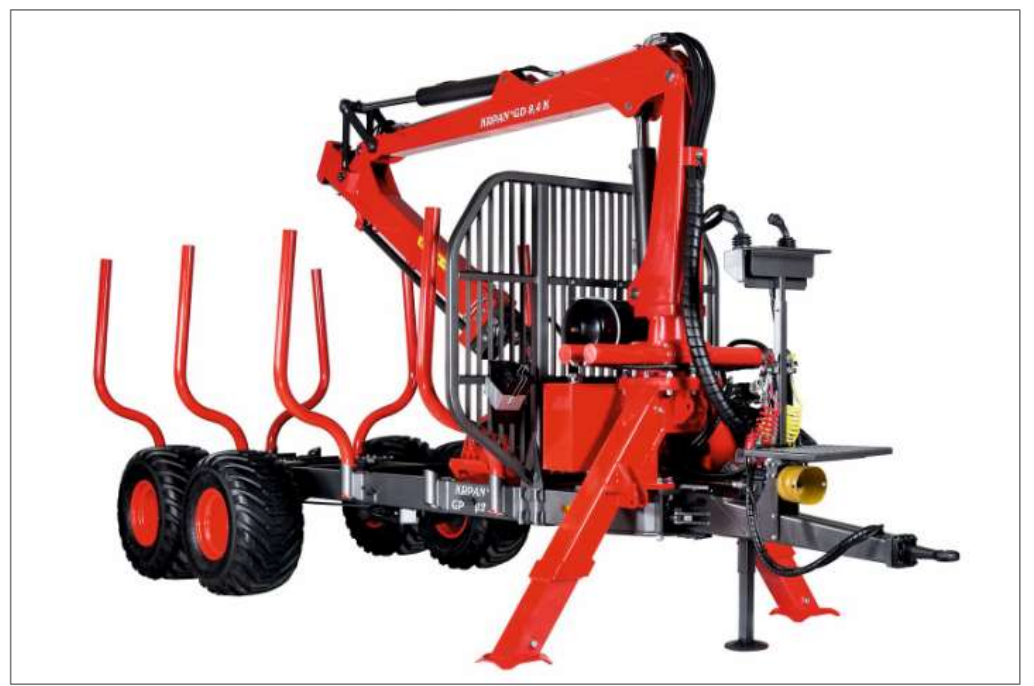

Photo 3. Krpan GP12 D forestry trailer (source: www.kwf-tagung.org)

Slika 3. Šumarska prikolica Krpan GP12 D (izvor: www.kwf-tagung.org)

In the Machines \& tools category, for the Computers/Measurement area of application:

- Nestle LH 50 laser caliper with one-hand operation - enables the fast, non-contact determination of diameters that simplifies the measurement of standing and lying timber when receiving timber and during forest inventories. Developed by: Gottlieb Nestle GmbH \& Grube KG (more at www g-nestle.de; www.grube.de).

In the Personal protective equipment category, for the Work safety/Ergonomics area of application:

- Stihl HS-Multi-Protect hedge trimmer protective trousers - innovative trousers that combine many protective functions and are designed specifically for gardening and landscaping. Developed by: Stihl AG \& Co.KG (more at www.stihl.de).

In the Accessories category, for the Work safety area of application:

- D2-Forest safety system - certified, easily retrofittable system specially developed for combined procedures that reduces the risks to people who must be in the immediate sphere of influence of forestry equipment (Photo 4). Developed by: Wahlers Forsttechnik GmbH (more at www.wahlers-forsttechnik.de). 


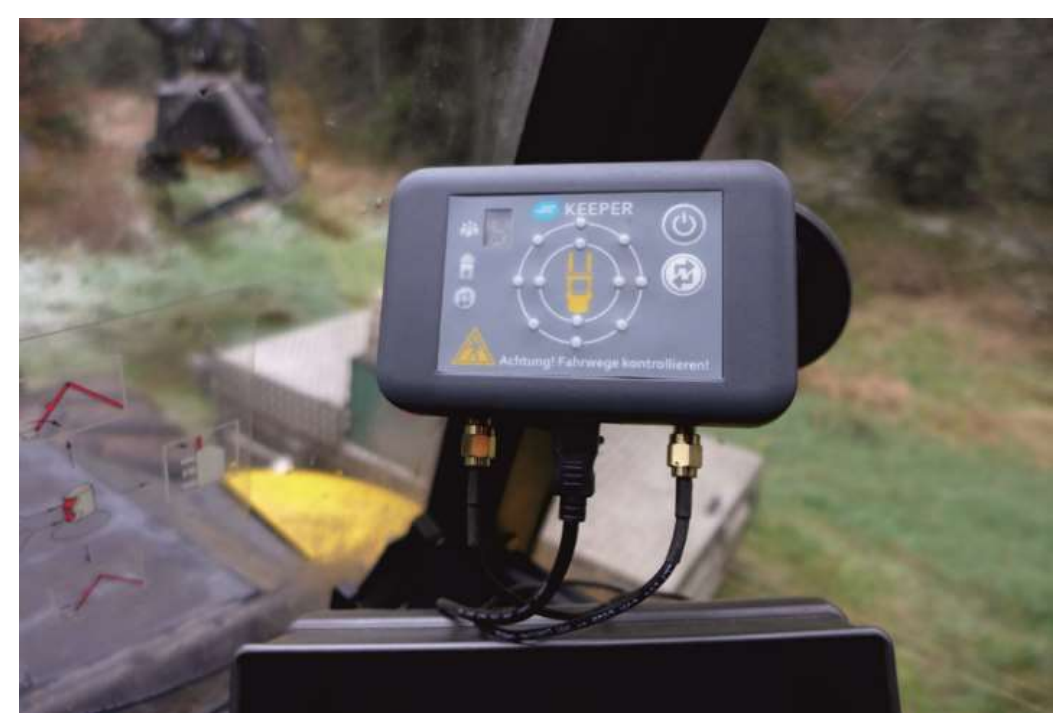

Photo 4. D2-Forest safety system innovation (source: www.kwf-tagung.org) Slika 4. Inovacija sigurnosni sustav D2-Forest (izvor: www.kwf-tagung.org)

In the Accessories category, for the Lubricants area of application:

- Kajo-Bio Longlife Grease LZR 2 - rapidly biodegradable lubricating grease suitable for all forestry machines which consists of $83 \%$ renewable raw materials. Developed by: Kajo-Schmierstoff-Technik GmbH (more at www.kajo.de). awarded to:

Additionally, the KWF-Vision awards for future-oriented thinking were

- Biofore Concept Car - pioneering development work and example of the innovative use of wood as a raw material in engineering and industrial design. Developed by: UPM \& the Helsinki Metropolia University of Applied Sciences (more at www.upm.com).

- HiVisionTM - innovative form of a crane control with novel camera-based 3D technologies providing improved functionality, ergonomics, and safety (Photo 5). Developed by: Hiab - Cargotec Germany GmbH (more at www.cargotec.com). 


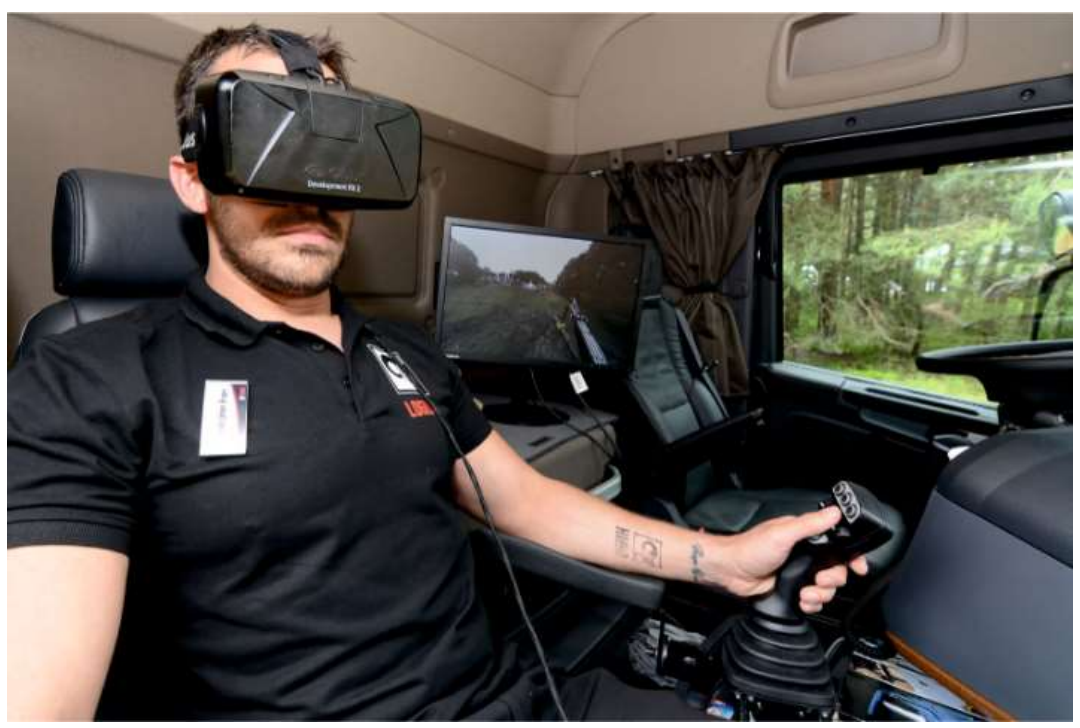

Photo 5. HiVisionTM innovation in crane control (source: www.kwf-tagung.org) Slika 5. Inovacija HiVisionTM u u pravljanju šumarskom dizalicom (izvor: $w$ ww.kwftagung.org)

\section{Innovation in Croatian Forestry - Inovacije u hrvatskom šumarstvu}

The status of innovation in Croatian forestry is described based on the previous research, i.e. questioning 286 employees of Croatian Forests Ltd on the company's innovation culture (Šporčić et al. 2014). Croatian Forests Ltd (CF) is the state-owned forest company which, manages 2 million hectares of forests and forest land (about $75 \%$ of the total forest area RC), employs approximately 7000 employees, and represents, along with a much smaller proportion of private and other forest owners, the main entity in forest management of Croatia.

The study revealed a low level of development and implementation of innovation in state forestry. Although the majority of CF employees (66\%) considers innovation to be of crucial importance for business efficiency, they mainly evaluate $\mathrm{CF}$ as not innovative company (Graph 1). 


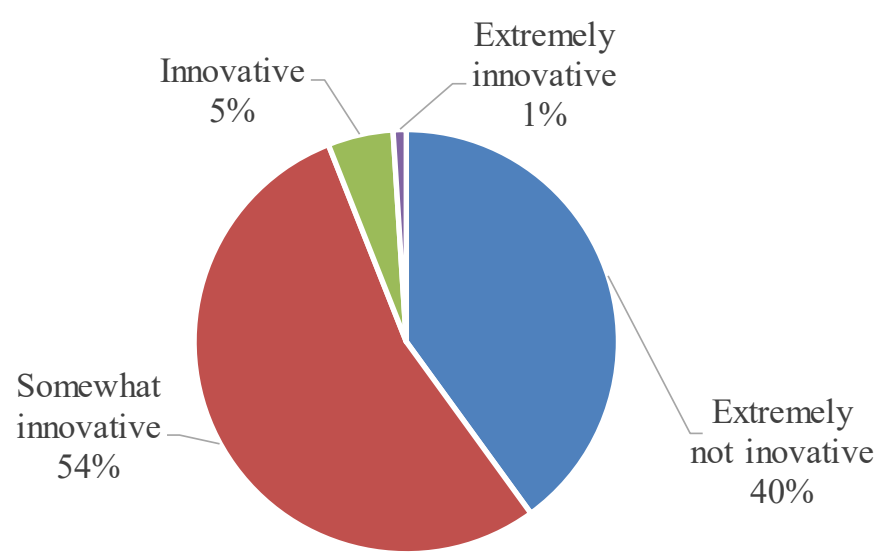

Graph 1. Innovation level of state forest company Croatian Forests Ltd.

Grafikon 1. Razina inovacije u državnom šumskom poduzeću Hrvatske šume d.o.o.

Regarding the type of innovation, process innovations are the most common, but still not very frequent. Innovations in other areas are extremely low, where $80 \%$ of the respondents state that product, marketing, and organization innovations are rare or nonexistent (Graph 2). In assessing the most needed types of innovations, organizational innovations are considered of vital importance for the development of the company, followed by marketing and process innovations. Only 5\% of employees or less, feels that innovations of any type are unnecessary (Graph 3).

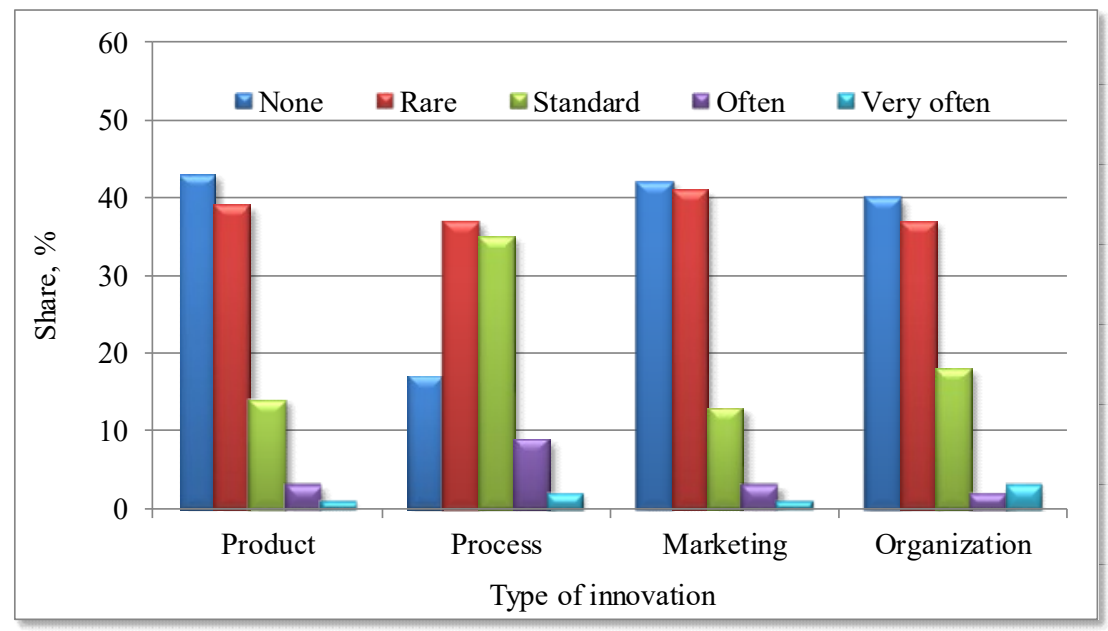

Graph 2. Type of developed and implemented innovations in Croatian Forests Ltd. Grafikon 2. Vrsta razvijenih i implementiranih inovacija u Hrvatskim šumama d.o.o. 


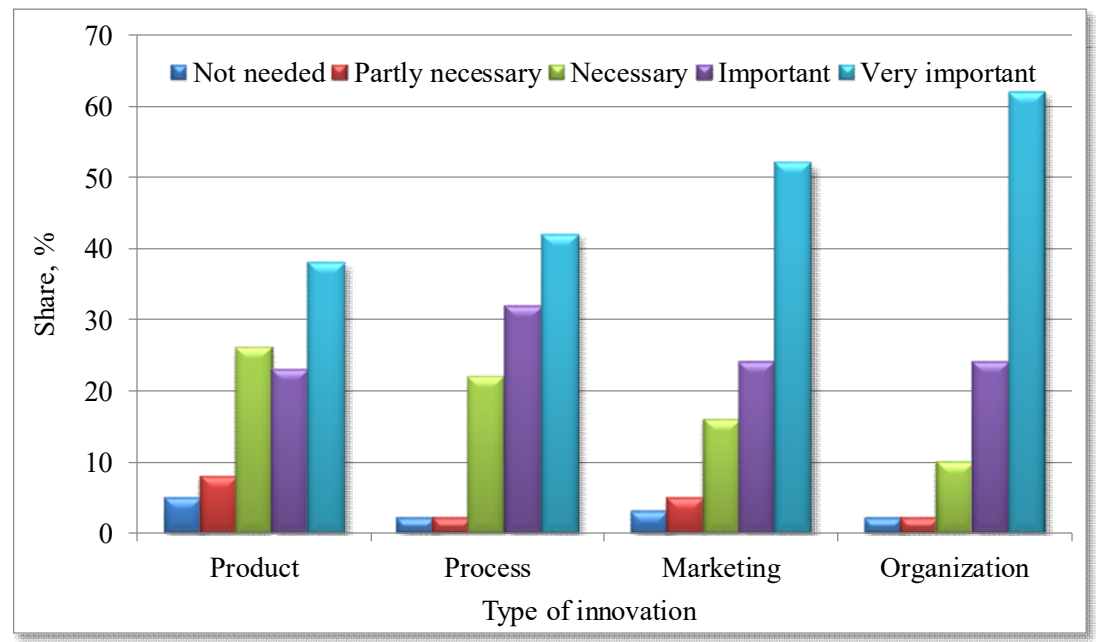

Graph 3. The most needed types of innovation in Croatian Forests Ltd. Grafikon 3. Najpotrebnije vrste inovacija u Hrvatskim šumama d.o.o.

The results showed that innovation is not receiving enough attention, and its inadequate treatment and poor position are reflected in following findings:

- $83 \%$ of respondents believe that company does not consider or rejects ideas and suggestions from employees without reasonable grounds; only $2 \%$ considers that company is open to innovation,

- $90 \%$ of respondents do not recognize an effective evaluation system of ideas within the company,

- $75 \%$ of respondents believe that the company is inefficient in decision making,

$-51 \%$ of respondents believe that they could enhance the production process performance,

- $57 \%$ of respondents think that they were not assigned to the workplace, which fully uses their potential,

- $90 \%$ think that level of personal income in the company does not depend on the results of one's work,

- $91 \%$ of respondents find that innovation and rationalization are not adequately rewarded.

The most common impediments for stronger innovation activity are recognized in insufficient financial means, administrative obstacles, regulations and unqualified personnel of the company. Finally, contrary to the expected positive influence of innovation on business results, most of the CF employees $(60 \%)$ perceived the impact of implemented innovations as neutral, with no effect on company's income whatsoever. 


\section{Regulation of innovation activity in the Croatian Forests Ltd. - Uređenje inovacijske djelatnosti u Hrvatskim šumama d.o.o.}

The regulation of innovation activities in state forestry is defined by "Ordinance on innovation activity in Croatian Forests Ltd." first adopted in 2007 and updated in 2011 [39]. This ordinance determines:

- types of innovation,

- organization of innovation activity,

- submission and acceptance of the innovation proposal

- rights and obligations of the author of innovation

- basics and criteria for evaluating innovative work

- other forms of stimulating innovation activities

The Ordinance defines mutual rights and obligations of the company and its employees concerning inventions, technological advancements, and rationalization (innovation). It states that $\mathrm{CF}$ as the employer acquires the right to exploitation of any authorship work incurred in performing the obligations arising from the employment relationship. Every employee, regardless of his regular work and tasks, which by innovative activity and other types of creativity contributes to increasing the profits or reducing the costs of $\mathrm{CF}$, is entitled to a special fee under the ordinance.

The main provisions related to encouraging innovation are the following.

Authors of the innovation acquire:

- the right to be acknowledged as authors of the innovation,

- the right to financial reward,

- the right to appropriate moral recognition,

- the right to an advantage in professional development and training,

- the right to assign names to their invention,

- the right to participate in demonstrations and exhibitions of the invention.

Depending on the significance of the innovation, authors realise a compensation over the course of time:

- for invention - during its application and the longest for the duration of the patent protection,

- for technological advancements, model and pattern (new product) - during its application, and the longest for three years from the start of its application,

- for useful proposition - during its application, and the longest for one year from the start of its application.

The amount of financial compensation for the accepted innovation is calculated by the formula:

$N=O \times F 1 \times F 2 \times F 3$

where:

$\mathrm{N}$ - amount of compensation in HRK

$\mathrm{O}$ - basis for calculation (annual savings/profits from application of innovation)

F1 - accepted constant on achieved savings/profits from innovation $(0.1)$ 
F2 - correction factor in relation to degree of innovation (1.2 - for patented invention; 1.0 - for technological advancements, model and pattern; 0.5 - for useful proposition) F3 - factor of creative ability and scope of work (1.0 - beyond the work task and scope of work; 0.8 - beyond the work task but within the scope of work; 0.5 - within the work task if it resulted in new quality.

According to the Ordinance, innovators are also entitled to a one-time financial reward in cases when the annual savings/profits cannot be determined, but the benefits of the innovation are obvious.

\section{DISCUSSION AND CONCLUSION - Rasprava $i$ zaključci}

Innovation is the cornerstone of successful business practice and a driving force in today's economy. At the level of a common European policy, innovation (integral element of the "Europe 2020" strategy) has been recognized as a crucial agent for the creation of economic growth, employment, and strengthening of rural area development. For many thriving companies, innovations are the key factor in their growth and development.

The importance and role of innovation have also been recognized in forestry, and in many developed countries, different projects and actions are being implemented related to the strengthening of innovative forestry activities. The forestry sector is nowadays, given the multiple economic, social and ecological functions of forest ecosystems as well as the sensitivity of forest management and forestry operations, exposed to numerous demands, pressures, and challenges. The answer to these challenges can certainly, to some extent, come from innovations, their development, application, and promotion. Innovation in forestry, just as in other sectors, can provide a significant boost to production and business operations, and contribute to competitiveness and success of forest companies and forest-based sector.

For strengthening of innovation in forestry, particularly important are the programs and initiatives aimed at promoting and honouring achieved innovations. Such programs are presented "Schweighofer Prize" and "KWF Innovation Medal" which continuously give recognition and award the most innovative forestry developments, ideas, technologies, products, and services. In this way, such programs greatly contribute to encouraging innovation activities in forestry and raise both public and profession awareness about the innovation in forestry.

Projects like "Schweighofer Prize" and "KWF Innovation Medal" are in the forest-based sector even more important than similar initiatives in other industries. Namely, forestry as a low-tech sector is traditionally characterized by a low level of innovation (Rametsteiner et al., 2005). A study in Croatian forestry has also determined a relatively unfavorable status of innovation in state forest company. Low innovation culture is reflected in rare innovation activities, lack of adequate incentives, bureaucratic obstacles, a non-efficient system for evaluating ideas, and poor perception of the innovations effect on company income.

A positive example from Croatian forestry is the "Ordinance on innovation activity in Croatian Forests Ltd." which was adopted to stimulate innovation in forest 
company, and it represents a formal framework for evaluating and rewarding innovations. The Ordinance defines mutual rights and obligations of the company and its employees regarding inventions, and as one of the main provisions determines the amount of financial reward for the authors of accepted innovation. However, keeping in mind the low status of innovation in $\mathrm{CF}$, the formal framework provided by the Ordinance doesn't seem sufficient for stronger innovation activity.

Stimulation of employee creativity and innovation primarily rests on innovation culture of the company, which encompasses high quality human potential management together with the climate of positive motivation where employees feel free to 'attempt and fail', are encouraged on innovative projects, and subsequently, receive an adequate reward for their contributions. At the same time, organizational adjustments are also needed to diminish bureaucratic and other obstacles that greatly hamper the path from idea to the realization of innovation.

For this direction, it is crucial to invest in research, education and infrastructure. National and company policies thereat play an important role in encouraging all relevant stakeholders on innovation. The priorities of a strategic approach to promoting innovation should be: empowering people to innovate, liberating innovation in companies, creation and use of knowledge, application of innovations for resolving global and social issues, and improvements in measuring and managing innovation.

Finally, development and promotion of innovation are regarded as a lever which can provide multiple benefits, improve performance, and ensure sustainable development of the forestry sector. Results of presented study and similar research can serve as an objective starting point and foundation for creating strategies for improvement of business and management practices in forestry, and encouragement of innovation in the forest sector.

\section{REFERENCES - Literatura}

AMABILE, T. M., CONTI, R., COON, H., LAZENBY, J., HERRON, M. (1996): Assessing the work environment for creativity. Academy of Management Journal, 39, 11541184.

BOSTON, K., LESHCHINSKY, B., KEMP, E., WORTMAN, R. (2017): The use of a rotary asphalt broom to groom aggregate forest roads. Croatian Journal of Forest Engineering, 38, 119-126.

CROATIAN FORESTS (CF) (2011): Ordinance on innovation activity in Croatian Forests Ltd. Zagreb, $5 \mathrm{p}$.

CROPLEY, D. H., (2009): Fostering and measuring creativity and innovation: individuals, organisations and products. In: Villalba (ed.) Measuring creativity, Proceedings for the conference "Can creativity be measured?" Brussels, 28-29, May 2009. p. 257-278. 
CUEVAS-VARGAS, H., ESTRADA, S., LARIOS-GÓMEZ, E. (2016): The effects of ICTs as innovation facilitators for a Greater business performance - evidence from Mexico. Procedia Computer Science, 91, 47-56.

EUROPEAN COMMISION (EC) (2010): Europe 2020 strategy. Available at: http://ec.europa.eu/europe2020/documents/related-document-type/index_en.htm

EUROPEAN COMMISION (EC) (2011): Horizon 2020 - The EU Framework Programme for Research and Innovation. Available at: https://ec.europa.eu/programmes/horizon2020

EUROPEAN COMMISION (EC) (2013): EU Forest Strategy. Available at: https://ec.europa.eu/agriculture/forest/strategy

JARSKÝ, V. (2015): Analysis of the sectoral innovation system for forestry of the Czech Republic. Does it even exist? Forest Policy and Economics, 59, 56-65.

KAAKKURIVAARA, T., KOLISOJA, P., UUSITALO, J., VUORIMIES, N. (2016): Fly ash in forest road rehabilitation. Croatian Journal of Forest Engineering, 37, 119-130.

KUBECZKO, K., RAMETSTEINER, E., WEISS, G. (2006): The role of sectoral and regional innovation systems in supporting innovations in forestry. Forest Policy and Economics, 8, 704-715.

LASKOVA, J., POSAVEC S. (2011): Forest management in Croatia focusing on innovation. Lesn. Čas. - Forestry Journal, 57, 134-142.

LUECKE, R., KATZ, R. (2003): Managing Creativity and Innovation. Boston, MA: Harvard Business School Press.

MADONSELA, N. S., MUKWAKUNGU, S. C., MBOHWA, C., (2017): Continuous innovation as fundamental enabler for sustainable business practices. Procedia Manufacturing, 8, 278-283.

MARTINIĆ, I., ŠPORČIĆ, M., VONDRA, V. (2006): Inovacijski procesi kao ključ provedbe Hrvatske šumarske politike (Innovation processes as key to implementation of Croatian Forestry Policy). Glasnik za šumske pokuse, sp.edition 5, 703-715.

MCPFEE (2003): Vienna Resolution 2 „Enhancing Economic Viability of Sustainable Forest Management in Europe". $4^{\text {th }}$ Ministerial Conference on the Protection of Forests in Europe, $28-30$ April 2003, Vienna, Austria. Available at: http://www.foresteurope.org/docs/MC/ MC_vienna_resolution_v2.pdf

MCPFEE (2015): Madrid Ministerial Resolution 1 „Forest sector in the center of Green Economy". $7^{\text {th }}$ Ministerial Conference on the Protection of Forests in Europe, 20 - 21 October 2015, Madrid, Spain. Available at: http://www.foresteurope.org/sites/default/files/ELM_7MC_2_2015_MadridResol ution1_GreenEconomy_adopted.pdf

NELSON, R., WINTER, S. (1977): In search of a useful theory of innovation. Research policy, 6, 36-77. 
OECD (2005): Guidelines for Collecting and Interpreting Innovation Data. Oslo Manual, 3rd edition. OECD, Statistical Office of the European Communities, Luxembourg, 10 Nov 2005. $162 \mathrm{p}$.

OJUROVIĆ, R., GRBAC, I. (2007): Kako ubrzati inovacije u šumarskom sektoru (How to accelerate innovation in the forestry sector). Šumarski list, 131, 181-187.

PEZDEVŠEK MALOVRH, Š., KUMER, P., GLAVONJIĆ, P., NONIĆ, D., NEDELJKOVIĆ, J., KISIN, B., AVDIBEGOVIĆ, M. (2017): Different organizational models of private forest owners as a possibility to increase wood mobilization in Slovenia and Serbia. Croatian Journal of Forest Engineering, 38, 127-140.

POSAVEC, S., ŠPORČIĆ, M., ANTONIĆ, D., BELJAN, K. (2011): Poticanje inovacija ključ razvoja u hrvatskom šumarstvu (Innovation fostering - key factor of development in Croatian forestry). Sumarski list, 135, 243-256.

POSAVEC, S. (2009): Europske inovacijske nagrade (European innovation awards). Šumarski list, 133, 458-459.

PRAJOGO, D. I. (2006): The relationship between innovation and business performance - a comparative study between manufacturing and service firms. Knowledge and Process Management, 13, 218-225.

RAMETSTEINER, E., WEISS, G., KUBECZKO, K. (2005): Innovation and entrepreneurship in forestry in central Europe. Leiden Brill Academic Publishers, $179 \mathrm{p}$.

RAMETSTEINER, E., WEISS, G. (2006): Innovation and innovation policy in forestry: Linking innovation process with systems models. Forest Policy and Economics, 8, 691-703.

ROGERS, E. M. (1995): Diffusion of Innovations. $4^{\text {th }}$ edition, The Free Press, New York.

SARVAŠOVA, Z., ŠÁLKA, J., DOBŠINSKÁ, Z., KOVALČíK, M. (2014): The comparison of innovations in Slovakian forestry between 2002 and 2010 - a shift to multifunctionality? South-east European Forestry, 5, 125-134.

SCHUMPETER, J. (1911): Theorie der ökonomischen Entwicklung, München. English edition 1934: The theory of economic development, Cambridge, Mass: Harvard University Press.

SEELAND, K., GODAT, J., HANSMANN, R. (2011): Regional forest organizations and their innovation impact on forestry and regional development in central Switzerland. Forest Policy and Economics, 13, 353-360.

SILVA, G. M., STYLES, C., LAGES, L. F. (2017): Breakthrough innovation in international business: The impact of tech-innovation and market-innovation on performance. International Business Review, 26, 391-404.

SRIĆA, V. (2003): Kako postati pun ideja (How to become full of ideas). MEP Consult, Zagreb, $192 \mathrm{p}$. 
STEELMAN, T. A. (2010): Implementing innovation - fostering enduring change in environmental and natural resource governance. Georgetown University press, Washington, DC, $224 \mathrm{p}$.

ŠPORČIĆ, M., LANDEKIĆ, M., MARJANOVIĆ, M. (2012): Vodič za prikupljanje podataka i interpretaciju inovacija u šumarstvu (Guidelines for Collecting Data and Interpreting Innovations in Forestry). Nova mehanizacija šumarstva, 33, 7994.

ŠPORČIĆ, M., POSAVEC, S., LANDEKIĆ, M., PENTEK, T., PORŠINSKY, T., LEPOGLAVEC, K. (2014): Development and implementation of innovations in Croatian forestry. Proceedings of JOINT $5^{\text {th }}$ Forest Engineering Conference (FEC) \& $47^{\text {th }}$ International Symposium on Forestry Mechanisation (FORMEC) „Forest Engineering: Propelling the Forest Value Chain”, Gerardmer, France, 2326 September 2014, 8 p.

WEISS, G., PETTENELLA, D., OLLONQVIST, P., SLEE, B. (EDS) (2011): Innovation in Forestry - Territorial and Value Chain Relationships. CABI Publishing, 319 p.

ZAIED, R. M. B., LOUATI, H., AFFES, H. (2015): The relationship between organizational innovations, internal sources of knowledge and organizational performance. International Journal of Managing Value and Supply Chains, 6, 5367.

ŽIVOJINOVIĆ, I., NEDELJKOVIĆ, J., STOJANOVSKI, V., JAPELJ, A., NONIĆ, N., WEISS, G., LUDVIG, A. (2017): Non-timber forest products in transition economies: Innovation cases in selected SEE countries. Forest Policy and Economics, 81, 18-29.

\section{SAŽETAK}

Rad se bavi promicanjem inovacija $u$ šumskom sektoru te prikazuje inicijative $\mathrm{i}$ koncepte koji imaju važnu ulogu u poticanju i jačanju inovacija u šumarstvu. Dva istaknuta međunarodna programa obuhvaćena radom uključuju "Schweighoferovu nagradu" koja predstavlja inovacijsku nagradu za europski šumarsko-drvni sektor i "KWF medalju za inovacije" koju dodjeljuje Kuratorium für Waldarbeit und Forsttechnik - KWF (Centar za šumarstvo i šumarstvo) za najinovativnija šumarska postignuća. Pregled odabranih programa uključuje postupak nominacije i ocjenjivanja inovacija, kategorije inovacija $\mathrm{i}$ nagrade, te posebno aktualne pobjednike, tj. nagrađene inovacije u šumarstvu. Dodatno, u radu se prikazuje stanje inovacija u hrvatskom šumarstvu te opisuju usvojena rješenja za poticanje inovacije u državnom šumarskom poduzeću. Cilj rada je naglasiti važnost razvoja i promicanja inovacija, podići razinu svijesti o inovacijama u šumarstvu te doprinijeti jačanju inovacijskih aktivnosti i razvoju inovacijske kulture u šumarskom sektoru.

Corresponding author: Mario Šporčić; University of Zagreb,Faculty of Forestry, Department of Forest Engineering, Svetošimunska 25, 10000 Zagreb, Croatia; email address: sporcic@sumfak.hr 